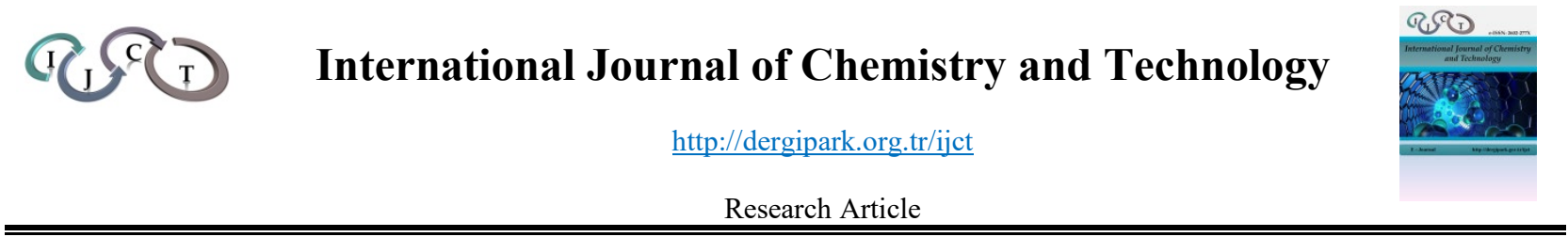

\title{
Comparison of quality properties of the Iranian Saffron (Crocus sativus L.) and Saffron grown in macro and micro locations in Turkey
}

\author{
Hasan ASIL ${ }^{1, *},(D)$ Ersen GÖKTÜRK ${ }^{2}$ \\ ${ }^{l}$ Medicinal and Aromatic Plants Program, Altınözü Vocational School of Agricultural Sciences, Hatay Mustafa Kemal \\ University, 31001, Hatay, Turkey \\ ${ }^{2}$ Department of Chemistry, Faculty of Science and Arts, Hatay Mustafa Kemal University, 31001, Hatay, Turkey
}

Received: 30 October 2021; Revised: 24 November 2021; Accepted: 25 November 2020

*Corresponding author e-mail: hasan.asil@hotmail.com

Citation: Asil, H.; Göktürk, E. Int. J. Chem. Technol. 2021, 5 (2), 108-116.

\section{ABSTRACT}

Volatile and bioactive compositions of saffron collected from different locations in Turkey and Iran were investigated using gas chromatography-mass spectrometry (GC-MS/FID and GCMS/MS) for identification and quantification of volatile compounds. Ultrasound-assisted extraction method using methanol:ethyl acetate solvent mixture was used to isolate the volatile components of saffron. This study revealed that the amounts of the volatile and bioactive compounds of saffron varied between different geographical locations. The most important bioactive compounds of saffron, safranal, crocin and crocetin, were also quantitatively analyzed in all saffron samples. The highest amount of safranal and crocin were observed in Hatay Yayladağı saffron with $22532.97 \mathrm{mg} \mathrm{kg}^{-1}$ and $647.26 \mathrm{mg} \mathrm{kg}^{-1}$, respectively. The highest amount of crocetin was obtained with $6.73 \mathrm{mg} \mathrm{kg}^{-1}$ in Ankara Ayaş saffron. While Hatay kırıkhan saffron contained the highest fraction of fatty acid content with $23.56 \%$, the highest fraction of bioactive components was discovered in Karabük Safranbolu ovacuma saffron with $90.84 \%$. According to the obtained outcomes, the highest qualities saffron were determined to be observed in Hatay Yayladağı and Karabük Safranbolu ovacuma saffron, respectively.

Keywords: Crocus sativus L., GC-MS analysis, Saffron, ultrasound-assisted extraction, volatile components.
İran safranı (Crocus sativus L.) ile Türkiye'nin makro ve mikro lokasyonlarında yetiştirilen safranın kalite özelliklerinin karşılaştırılması

ÖZ

İran ve Türkiye'nin farklı lokasyonlardan toplanan safranın uçucu ve biyoaktif bileşimleri, uçucu bileşiklerin tanımlanması ve miktar tayini için gaz kromatografisi-kütle spektrometrisi (GC-MS/FID ve GC-MS/MS) kullanılarak araştırılmıştır. Safranın uçucu bileşenlerini izole etmek için metanol:etil asetat çözücü karışımı kullanılarak ultrason destekli ekstraksiyon yöntemi kullanılmıştır. Bu çalışma, safranın uçucu ve biyoaktif bileşiklerinin miktarlarının farklı coğrafi konumlar arasında doğrulandığını ortaya koymak için yapılmıştır. Safran, safranal, krosin ve krosetin gibi en önemli biyoaktif bileşikler de tüm safran örneklerinde kantitatif olarak analiz edilmiștir. En yüksek safranal ve krosin sirasıyla $22532.97 \mathrm{mg} \mathrm{kg}^{-1}$ ve 647.26 $\mathrm{mg} \mathrm{kg}^{-1}$ ile Hatay Yayladağı safranında gözlemlendi. En yüksek krosetin miktarı $6.73 \mathrm{mg} \mathrm{kg}^{-1}$ ile Ankara Ayaş safranında elde edilmiştir. Yağ asidi içeriği en yüksek fraksiyon \%23.56 ile Hatay Kırıkhan safranı içerirken, biyoaktif bileşenlerin en yüksek fraksiyonu \%90.84 ile Karabük Safranbolu ovacuma safranında bulunmuştur. Elde edilen sonuçlara göre en yüksek kalite safranın Hatay Yayladağı ve Karabük Safranbolu ovacuma safranında gözlendiği belirlenmiştir.

Anahtar Kelimeler: Crocus sativus L., GC-MS analizi, Safran, ultrason destekli ekstraksiyon, uçucu bileşenler.

\section{INTRODUCTION}

Saffron (Crocus sativus L.) is a highly valued herb because of its stigmas, which are widely used as spice, medicinal drugs and food additives. Saffron has an important pharmacological potential and is economically valuable spice. The saffron plant has a wide history of use in traditional medicinal treatment or prevention of different types of diseases, including cancer. ${ }^{1-3}$ The dried saffron stigma contains crocin, safranal and picrocrocin, 
and these photochemical substances are responsible for the color, aroma and taste of the saffron. ${ }^{4}$ Crocetin is an aglycone part of naturally occurring crocin and is produced in biological systems as a hydrolytically bioactive metabolite. ${ }^{5,6}$ Studies on the pharmacological activities of crocetin have shown that this aglycone is a therapeutically useful bioactive metabolite. ${ }^{6}$

The quality of saffron is chemically determined by the existence of three main secondary metabolites; crocin (water-soluble crocetin esters), picrocrocin (monoterpene glycoside and safranal precursor) and safranal (an important essential oil component) are responsible for colour and bitter taste of saffron. These metabolites are essential for the quality of saffron. The amounts of these metabolites in saffron vary according to the geography where saffron is grown, and therefore, geographical origin is very important for high quality saffron production. ${ }^{7,8}$ To increase product profitability, many researchers are working on the evaluation of saffron by-products such as tepals, stamens, styles, leaves and corms. ${ }^{9,10}$

Saffron, which can be grown in tropical and subtropical climates in the northern hemisphere, is successfully grown in various ecologies up to $2000 \mathrm{~m}$ high altitude. One of the origins of saffron is Anatolian ecology. Although most of the parts of Turkey have suitable ecology for saffron cultivation, saffron is widely grown in safranbolu region. ${ }^{11}$ There is no information about the first origin of saffron around the world, but Iran is reported to be the first origin for saffron production and then, it was spreaded out to Turkey and Greece. However, today saffron is successfully grown in Spain, Italy, France, Switzerland, Morocco, Egypt, Israel, Azerbaijan, Pakistan, India, New Zealand, Australia and Japan. Total saffron production around the world is about 205 tons; Iran 160 tons $(\sim 80 \%)$, India $8-10$ tons $(\sim 5 \%)$, Greek 4-6 tons $(\sim 3 \%)$, Morocco $0.8-1$ tons $(\sim 0.5 \%)$, Spain $0.3-0.5$ tons $(\sim 0.25 \%)$ and the rest of it was produced by other countries. ${ }^{12,13}$ According to the literature, location and saffron corms from different

2.2. Preparation of standard substances and extraction procedure

$0.5 \mathrm{mg} \mathrm{mL}-1$ safranal, crocin ve crocetin standard solutions were prepared in ethanol, diluted with 10 $2.000 \mathrm{ng} \mathrm{mL}-1$ concentrations and stored at $4{ }^{\circ} \mathrm{C}$. The extractions of saffron stigma samples were accomplished using the ultrasonic-assisted solvent extraction method. $100 \mathrm{mg}$ of stigma was grinded and put in a flask. 1.8-4.2 $\mathrm{mL}$ of methanol:ethyl acetate $(30: 70)$ mixture was then added to the flask. Obtained mixture was then sonicated in an ultrasonic bath for $15 \mathrm{~min}$. After sonication, obtained extract was centrifuged for $3 \mathrm{~min}$ at $5000 \mathrm{rpm}$. This process was repeated three times and obtained supernatants were collected in a different flask. The origins can have an impact on saffron productivity and quality. ${ }^{14}$ Fatty acid components are analyzed by GC-MS and GC-MS FID. ${ }^{15,16,17}$

Today, many researchers have focused on the identification of new volatile compounds in saffron and new analytical techniques. Sample characterization is generally neglected. Some researchers purchase saffron and analyze it without paying attention to its origin or originality. ${ }^{18}$ The main objective of this study is to compare the qualities of saffron obtained from different locations. Specifically, it was aimed to compare the qualities of Iranian saffron, which is known to be the main production area of saffron around the World, and macro and micro-locations in Turkey. Saffron samples were collected from the different cities (macro) and their counties (micro) in Turkey. The amounts of safranal, crocin, crocetin, volatile compounds, fatty acids and bioactive components of the obtained samples were evaluated to discriminate the qualities of the collected saffron samples.

\section{MATERIALS AND METHODS}

Saffron samples were obtained from traditional production areas. The saffron stigmas were dried at room temperature for two days following harvest and placed in $1 \mathrm{~g}$ glass jars with lids. samples were received from the production areas by cargo. Iranian saffron was obtained from the province of Rezevi Khorasani. Saffron stigma samples in Turkey were obtained from different locations including Hatay (Kirıkhan, Iskenderun, Hassa and Yayladağı counties), Karabük (Safranbolu county Yukarıbucak and Ovacuma villages), Ankara (Ayaş, Nallıhan and Polatlı counties), Çukurova region (AdanaCukurova, Mersin-Tarsus and Osmaniye-Kadirli counties) and Antalya (Korkuteli county). The altitude and coordinate information of saffron production locations are given in Table 1 . Safranal $\geq 90 \%$ stabilized, (W338907-Sample-K), crocetin dialdehyde (18804-10 MG) and crocin (17304-1G) standards were purchased from Sigma Aldrich and used as received.

solvent mixture was evaporated with a final volume of 1 $\mathrm{mL}$ and obtained extracts were stored at $+4{ }^{\circ} \mathrm{C}$ in the dark for GC-MS analyses. ${ }^{4,19}$

2.3. Gas Chromatography- Tandem mass spectrometry (GC-MS/MS) analysis

Volatile components of saffron samples were identified by GC-MS/MS (Hewlett-Packard 6890) instrument equipped with HP-5MS fused silica column (5\% phenyl methyl polysiloxane $30 \mathrm{~m} 0.25 \mathrm{~mm}$ i.d.. film thickness $0.25 \mu \mathrm{m})$ and Hewlett-Packard mass selective detector 6890. GC-MS/MS analyses were carried out under the same conditions reported in the literature. 4, 19, 20 
Table 1. Altitude and coordinate information of safran production locations

\begin{tabular}{|c|c|c|c|c|}
\hline Macro & Micro & Elevation & $\begin{array}{l}\text { Longitude } \\
\text { (E) }\end{array}$ & $\begin{array}{c}\text { Latitude } \\
\text { (N) }\end{array}$ \\
\hline \multirow{4}{*}{ HATAY } & Kırıkhan & 122 & 3636 & 3122 \\
\hline & İskenderun & 10 & 3636 & 3508 \\
\hline & Hassa & 288 & 3636 & 4230 \\
\hline & Yayladağ1 & 711 & 3636 & 0208 \\
\hline \multirow{2}{*}{ KARABÜK } & $\begin{array}{l}\text { Safranbolu } \\
\text { Yukarıçiflik }\end{array}$ & 829 & 4132 & 1743 \\
\hline & Safranbolu Ovacuma & 376 & 4132 & 2745 \\
\hline \multirow{3}{*}{ ANKARA } & Ayaş & 902 & 4032 & 0118 \\
\hline & Nallihan & 596 & 4031 & 0920 \\
\hline & Polatli & 811 & 3932 & 3511 \\
\hline \multirow{3}{*}{ ÇUKUROVA } & Adana Çukurova & 95 & 3735 & 0609 \\
\hline & Tarsus & 35 & 3634 & 5735 \\
\hline & Osmaniye Kadirli & 94 & 3736 & 2304 \\
\hline ANTALYA & Korkuteli & 871 & 3730 & 0319 \\
\hline IRAN & $\begin{array}{l}\text { Rezaviye } \\
\text { Horasani }\end{array}$ & 955 & 3659 & 1636 \\
\hline
\end{tabular}

2.4. Gas Chromatography-Mass spectrometry flame ionization detector (GC-MS/FID) analysis

The amounts of safranal, crocin and crocetin were detected by GC-MS/FID (Hewlett-Packard 6890) instrument equipped with HP-88 fused silica column $(100 \mathrm{~m} 0.25 \mathrm{~mm}$ i.d.. film thickness $0.25 \mu \mathrm{m})$ and Hewlett-Packard mass selective detector 6890 . The oven was heated to $60{ }^{\circ} \mathrm{C}$ and waited for $1 \mathrm{~min}$ at that temperature. Then, the temperature was raised to $100{ }^{\circ} \mathrm{C}$ by $5{ }^{\circ} \mathrm{C} \mathrm{min}^{-1}$ and waited for $4 \mathrm{~min}$. The temperature was increased by $5{ }^{\circ} \mathrm{C} \mathrm{min}{ }^{-1}$ to $135^{\circ} \mathrm{C}$ and waited for $20 \mathrm{~min}$. Finally, it was increased by $10{ }^{\circ} \mathrm{C} \min ^{-1}$ to $170{ }^{\circ} \mathrm{C}$ and waited for $22 \mathrm{~min}$. The gas mixture to the flame was made of $60 \mathrm{~mL} \mathrm{~min}^{-1}$ of $\mathrm{H} 2$ (UHP grade), $400 \mathrm{~mL} \mathrm{~min}^{-1}$

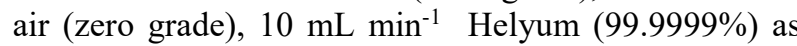
carrier gas. Injector temperature was kept at $200{ }^{\circ} \mathrm{C} .{ }^{4,} 19$

\section{RESULTS AND DISCUSSION}

In this study, the quality of saffron samples obtained from different locations was evaluated using two different aspects. First, evaluation involved in some quality comparisons of saffron samples obtained from 13 different micro-locations in five different macro locations in Turkey and Iranian saffron. In both studies, the volatile components in the stigma samples were determined by GC-MS/MS analysis. The amount of active ingredients indicating the quality of saffron such as safranal, crocin and crocetin in the stigma were determined by GC-MS/FID analysis. Both analysis methods are explained comparatively.

\subsection{Comparisons of the qualities of saffron samples}

Safranal fractions of Iranian saffron and saffron grown in different locations in Turkey and the amounts of safranal, crocin and crocetin in these saffron samples were summarized in Table 2. According to the Table 1, the highest fractions of safranal were obtained with the order by $86.88 \%$ Safranbolu Ovacuma saffron in Karabük, $75.48 \%$ Yayladağ 1 saffron in Hatay, $70.23 \%$ Polatl saffron in Ankara, 68.58\% Osmaniye Kadirli in Çukurova. Safranal fraction in Iranian saffron was found to be $64.66 \%$. When safranal fractions were compared, the highest amount of safranal was observed in Safranbolu Ovacuma saffron in Karabük with $86.88 \%$. Safranal, which is the most abundant volatile component in saffron, was reported to constitute $60-70 \%$ of the volatile components in saffron in the literature. ${ }^{21}$ In another report, it was reported that $93 \%$ of safranal was found in the saffron sample according to the olfactometric. $^{22}$

In another study, the fractions of safranal in Spanish saffron collected from different locations were found to be $77.7 \%$ (SF-SP4), 73.2\% (SF-SP3), 64.5\% (SF-SP2), SF-SP6 (50.7\%), 32.1\% (SF-SP1) and 29.8\% (SF-SP5). Significant differences on the safranal fractions were observed among the different locations. Such differences were reported to be due to different agricultural practices or drying methods of saffron. ${ }^{23}$ 
Table 2. Comparison of the safranal fractions and the amounts of safranal, crocin and crocetin compounds obtained from Iranian saffron and saffron from micro and macro locations in Turkey.

\begin{tabular}{|c|c|c|c|c|c|}
\hline \multicolumn{2}{|c|}{ Location } & \multirow{2}{*}{$\begin{array}{c}\text { GC-MS/MS } \\
\text { Safranal } \\
(\%)\end{array}$} & \multicolumn{3}{|c|}{ GC-MS/FID } \\
\hline Macro & Micro & & $\begin{array}{c}\text { Safranal } \\
\text { (mg/kg) }\end{array}$ & Crocin (mg/kg) & Crocetin (mg/kg) \\
\hline \multirow{4}{*}{ HATAY } & Kirıkhan & 24.47 & 5422.74 & 379.84 & 1.30 \\
\hline & İskenderun & 29.31 & 7828.07 & 91.80 & 5.98 \\
\hline & Hassa & 28.56 & 3253.14 & 284.66 & 0.70 \\
\hline & Yayladağ1 & 75.48 & 22532.97 & 647.26 & 3.40 \\
\hline \multirow{2}{*}{ KARABÜK } & $\begin{array}{l}\text { Safranbolu } \\
\text { Yukarıçiflik }\end{array}$ & 64.10 & 12095.55 & 77.56 & 0.20 \\
\hline & $\begin{array}{l}\text { Safranbolu } \\
\text { Ovacuma }\end{array}$ & 86.88 & 21776.36 & 157.04 & 2.20 \\
\hline \multirow{3}{*}{ ANKARA } & Ayaş & 68.88 & 20609.74 & 526.04 & 6.73 \\
\hline & Nallihan & 66.97 & 14439.36 & 241.93 & 3.52 \\
\hline & Polatli & 70.23 & 16764.30 & 488.86 & 5.10 \\
\hline \multirow{3}{*}{ ÇUKUROVA } & Adana Çukurova & 65.53 & 14681.35 & 223.46 & 3.26 \\
\hline & Tarsus & 57.48 & 15717.08 & 534.35 & 0.02 \\
\hline & Osmaniye Kadirli & 68.58 & 14942.37 & 225.76 & 1.97 \\
\hline ANTALYA & Korkuteli & 34.67 & 4450.01 & 221.23 & 2.20 \\
\hline IRAN & Rezevi Horasani & 64.66 & 14678.80 & 358.38 & 5.80 \\
\hline
\end{tabular}

The amounts of safranal significantly differed among the different locations. The highest amount of safranal was observed in the order by Yayladağ1 saffron with $22532.97 \mathrm{mg} \mathrm{kg}^{-1}$, Safranbolu Ovacuma saffron with $21776.36 \mathrm{mg} \mathrm{kg}^{-1}$, Ayaş saffron with $20609.74 \mathrm{mg} \mathrm{kg}^{-1}$, Tarsus saffron with $15717.08 \mathrm{mg} \mathrm{kg}^{-1}$ and Korkuteli saffron with $4450.01 \mathrm{mg} \mathrm{kg}^{-1}$. The amount of safranal in Iranian saffron was $14648.80 \mathrm{mg} \mathrm{kg}^{-1}$. In the literature, the average amount of safranal in different locations was examined and results showed that safranal was obtained with $335.9 \mathrm{~g} \mathrm{~kg}^{-1}$ in Spanish saffron and $488.6 \mathrm{~g} \mathrm{~kg}^{-1}$ in Greek saffron. The geography plays an important role for the amounts of safranal found in saffron among different farming locations, especially in the regions of Greece, Iran, Italy and Spain, but no significant difference was observed between Iranian and Spanish saffron. ${ }^{24}$ The amounts of safranal from 76 commercially available saffron samples in different countries varied between 1.35 and $10.56 \mathrm{~g} \mathrm{~kg}^{-1}$ by the GC-MS/FID analysis. ${ }^{25}$

According to GC-MS/FID analysis results, the highest amounts of crocin in the macro locations was obtained in the order of Yayladağ 1 saffron in Hatay with $647.26 \mathrm{mg}$ $\mathrm{kg}^{-1}$, Tarsus saffron in Çukurova with $534.35 \mathrm{mg} \mathrm{kg}^{-1}$, Ayaş saffron in Ankara with $526.04 \mathrm{mg} \mathrm{kg}^{-1}$, Korkuteli saffron in Antalya with $221.23 \mathrm{mg} \mathrm{kg}^{-1}$ and Safranbolu Ovacuma saffron in Karabük with $157.04 \mathrm{mg} \mathrm{kg}^{-1}$ (Table 2). The amount of crocin in Iranian saffron was found to be $358.38 \mathrm{mg} \mathrm{kg}^{-1}$. As seen in the Table 2, the highest amount of crocin was observed in Hatay Yayladağ 1 saffron with $647.26 \mathrm{mg} \mathrm{kg}$. Crocin amounts in some locations in Turkey, especially Yayladağ 1 and Kırıkhan in Hatay, Ayaş and Polatlı in Ankara and Tarsus in Çukurova locations, are found to be higher compared to the Iranian saffron. In the literature, the amounts of crocin under different locations, drying conditions and 20 months storage period were reported to be $333.33 \mathrm{mg} \mathrm{kg}^{-}$ ${ }^{1}$ in Tehran and $293.33 \mathrm{mg} \mathrm{kg}^{-1}$ in Alborz in Iran. ${ }^{26}$ This study shows that the amounts of crocin obtained from Iranian saffron are very close to our findings. When the crocetin amounts were evaluated according to GCMS/FID analysis results, the highest crocetin amounts were obtained in the order of Ayaş saffron in Ankara with $6.73 \mathrm{mg} \mathrm{kg}^{-1}$, Iskenderun saffron in Hatay with $5.98 \mathrm{mg}$ $\mathrm{kg}^{-1}$, Adana Çukurova saffron in Çukurova with $3.26 \mathrm{mg}$ $\mathrm{kg}^{-1}$, Safranbolu Ovacuma saffron in Karabük with 2.20 $\mathrm{mg} \mathrm{kg}^{-1}$ and Korkuteli saffron in Antalya with $2.20 \mathrm{mg}$ $\mathrm{kg}^{-1}$. The amount of crocetin in Iranian saffron was 5.80 mg kg-1. The highest amount of crocetin was observed in Ayaş saffron in Ankara with $6.73 \mathrm{mg} \mathrm{kg}^{-1}$.

\subsection{Evaluation of major components in saffron samples}

Major components of saffron samples grown in Iran and different locations in Turkey are presented in Table 3. Six most abundant volatile components found in saffron samples identified by GC-MS/MS analysis are shown in Table 3. 
Table 3. Major volatile components of saffron samples obtained in Iran and macro and micro locations in Turkey.

\begin{tabular}{|c|c|c|c|c|c|c|}
\hline \multicolumn{7}{|c|}{ The fractions $(\%)$ of major components observed in saffron grown in Hatay macro climate } \\
\hline & Rt & Volatile components & Kirıkhan & İskenderun & Hassa & Yayladağı \\
\hline 1 & 12.706 & Safranal & 24.47 & 29.51 & 28.56 & 75.48 \\
\hline 2 & 38.696 & Glyceryl Arachidate & 20.71 & 20.16 & 15.48 & 5.32 \\
\hline 3 & 33.429 & Linoleic Acid & 9.53 & 2.65 & 0.38 & 0.34 \\
\hline 4 & 31.481 & Palmitic Acid & 5.47 & 3.52 & 4.95 & 1.89 \\
\hline 5 & 33.302 & Stearolic Acid & 4.04 & 4.59 & 8.40 & 3.07 \\
\hline 6 & 39.466 & Oleoamide & 2.79 & 7.13 & 2.65 & 0.90 \\
\hline & & & 67.01 & 67.56 & 60.42 & 87.00 \\
\hline
\end{tabular}

The fractions (\%) of major components observed in saffron grown in Karabük macro climate

Safranbolu Yukarıçiftlik

$12.706 \quad$ Safranal

Glyceryl Arachidate

Safranbolu Ovacuma

38.696

18.905

2,6,6-Trimethyl-4-Hydroxy-1-Cyclohexene-1-

64.10

Carboxaldehyde

33.302

31.481

Stearolic Acid

7.45

86.90

Palmitic Acid

2,3-Dihydro-3,5-Dihydroxy-6-Methyl-4H-Pyran-

1.43

3.46

4-One

\begin{tabular}{rr}
3.06 & 1.23 \\
2.60 & 0.92 \\
\hline 0.73 & 0.69
\end{tabular}

The fractions (\%) of major components observed in saffron grown in Ankara macro climate

12.706

38.696

39.466

33.302

31.481

33.465

\section{Ayaş}

68.90

8.62

3.56

2.47

1.65

1.44

86.64

79.37

ic Acid

Linolenic Acid Methyl Ester
Nallıhan

66.97

6.68

1.10

6.36

2.67

2.05

85.83

macro climate

Mersin

Tarsus

57.5

7.48

6.20

0.00

0.63

1.70

1.70
Polatlı

70.20

5.55

1.18

2.90

0.00

0.18

80.01

Stearolic Acid

4.22

2.40

2.36

2,3-Dihydro-3,5-Dihydroxy-6-Methyl-

1.26

73.51

Osmaniye

Kadirli

68.6

6.94

2.23

1.94

0.33

82.72

1.38

The fractions (\%) of major components observed in saffron grown in Antalya macro climate

12.706

38.696

33.302

31.481

17.661

11.182

Safranal

Glyceryl Arachidate

Stearolic Acid

Palmitic Acid

Isopropylidenecyclopropyl Methyl Ketone

2,3-Dihydro-3,5-Dihydroxy-6-Methyl-4H-Pyran-4-One

81.42

The fractions (\%) of major components observed in saffron grown in Iran macro climate

Linoleic Acid

Palmitic Acid 
These six components have been detected as major volatile components of the saffron stigmas. The second most abundant component of the saffron samples for all locations was found to be glyceryl arachidate. The highest amount of volatile components in saffron samples were observed in the order of Safranbolu Ovacuma saffron in Karabük with $94.95 \%$, Hatay Yayladağ 1 saffron with $87.00 \%$, Ankara Ayaş Saffron with $86.64 \%$, Adana Çukurova saffron with $82.72 \%$ and Antalya Korkuteli Saffron with $82.72 \%$. The amount of major volatile components in the Iranian saffron was found to be $82.01 \%$.

\subsection{Evaluation of essential fatty acid components}

According to the obtained results, saffron samples contained significant amounts of fatty acids as major components. It was observed that saffron samples contain very rich essential fatty acid compositions including palmitic acid, pentadecanoic acid, stearolic acid, linoleic acid, linolenic acid methyl ester, stearic acid and oleoamide. These fatty acids found in saffron samples are shown in Table 4 . The highest amounts of fatty acids found in saffron samples are observed with $23.56 \%$ from Kırıkhan saffron in Hatay, $13.79 \%$ from Antalya saffron, $13.40 \%$ from Nallıhan saffron in Ankara, 11.31\% from Mersin Tarsus saffron and $9.76 \%$ from Safranbolu Yukarıçiftlik saffron in Karabük. The fatty acid fraction in the Iranian saffron is detected to be $10.36 \%$. Table 4 shows that fractions of the volatile fatty acids in saffron stigmas are quite high, such amounts of fatty acids is considered to be very important for both human health and saffron quality. Tables 4 also shows that stearolic acid seems to be the most abundant fatty acid found in saffron stigmas for all locations. In the literature, differences between the amounts of saturated and unsaturated fatty acids in saffron pollens were found to be quite high. Omega acids $(3,6,7,9)$ including linolenic acid have been reported to be found among the unsaturated fatty acids. ${ }^{9}$

Table 4. Volatile fatty acids obtained from Iranian saffron and saffron samples from micro and macro locations in Turkey.

\begin{tabular}{|c|c|c|c|c|c|c|c|c|c|}
\hline \multirow[b]{2}{*}{$\begin{array}{c}\text { Macro } \\
\text { Locations }\end{array}$} & \multirow[b]{2}{*}{$\begin{array}{l}\text { Micro } \\
\text { Locations }\end{array}$} & \multirow[b]{2}{*}{$\begin{array}{l}\text { Palmitic } \\
\qquad(\%)\end{array}$} & \multicolumn{2}{|c|}{ Fatty acid fractions (\%) } & \multirow[b]{2}{*}{$\begin{array}{l}\text { Linoleic } \\
(\%)\end{array}$} & \multirow[b]{2}{*}{$\begin{array}{c}\text { Linolenic } \\
\text { Methyl } \\
\text { Ester }(\%)\end{array}$} & \multirow[b]{2}{*}{$\begin{array}{l}\text { Stearic } \\
(\%)\end{array}$} & \multirow[b]{2}{*}{$\begin{array}{c}\text { Oleoamide } \\
(\%)\end{array}$} & \multirow[b]{2}{*}{$\begin{array}{r}\text { Total } \\
\text { (\%) }\end{array}$} \\
\hline & & & $\begin{array}{c}\text { Pentadecanoic } \\
(\%)\end{array}$ & $\begin{array}{c}\text { Stearolic } \\
(\%)\end{array}$ & & & & & \\
\hline \multirow{4}{*}{ HATAY } & Kırıkhan & 5.47 & 0.54 & 4.04 & 9.53 & 0.00 & 1.19 & 2.79 & 23.56 \\
\hline & İskenderun & 3.52 & 0.54 & 4.59 & 2.65 & 0.00 & 1.13 & 7.13 & 19.56 \\
\hline & Hassa & 4.95 & 0.00 & 8.40 & 0.38 & 0.00 & 1.39 & 2.65 & 17.77 \\
\hline & Yayladağ1 & 1.89 & 0.00 & 3.07 & 0.34 & 1.12 & 0.52 & 0.90 & 7.84 \\
\hline \multirow{2}{*}{ KARABÜK } & $\begin{array}{c}\text { Safranbolu } \\
\text { Yukarıçiflik }\end{array}$ & 2.60 & 0.41 & 3.06 & 0.31 & 1.98 & 0.00 & 1.40 & 9.76 \\
\hline & $\begin{array}{l}\text { Safranbolu } \\
\text { Ovacuma }\end{array}$ & 0.92 & 0.19 & 1.23 & 0.00 & 0.00 & 0.31 & 0.49 & 3.14 \\
\hline \multirow{3}{*}{ ANKARA } & Ayaş & 1.65 & 0.00 & 2.47 & 0.23 & 1.44 & 0.00 & 3.56 & 9.35 \\
\hline & Nallihan & 2.67 & 0.23 & 6.36 & 0.22 & 2.05 & 0.77 & 1.10 & 13.40 \\
\hline & Polatli & 0.00 & 0.27 & 2.90 & 0.28 & 0.18 & 2.66 & 1.18 & 7.47 \\
\hline \multirow{3}{*}{ ÇUKUROVA } & $\begin{array}{c}\text { Adana } \\
\text { Çukurova }\end{array}$ & 2.40 & 0.00 & 4.22 & 0.29 & 0.00 & 1.23 & 0.99 & 9.13 \\
\hline & Tarsus & 0.00 & 0.44 & 6.20 & 0.41 & 0.00 & 3.21 & 1.05 & 11.31 \\
\hline & $\begin{array}{l}\text { Osmaniye } \\
\text { Kadirli }\end{array}$ & 1.94 & 0.39 & 2.23 & 0.36 & 0.00 & 0.74 & 0.91 & 6.57 \\
\hline ANTALYA & Korkuteli & 0.00 & 0.63 & 0.00 & 0.56 & 4.25 & 7.14 & 1.21 & 13.79 \\
\hline IRAN & $\begin{array}{c}\text { Rezevi } \\
\text { Horasanı }\end{array}$ & 2.46 & 0.33 & 2.10 & 3.84 & 0.00 & 0.94 & 0.69 & 10.36 \\
\hline
\end{tabular}

\subsection{Evaluation of the bioactive components}

Comparison of the bioactive components (drug, food, pharmacological) of the Iranian saffron and saffron grown in different locations in Turkey are given in Table 5. Bioactive components were identified with literature searches (PubChem and Sigma Aldrich Research Databases). Volatile fatty acids found in saffron samples are already shown in Table 4 and therefore, they are not included in Table 4. Safranbolu Ovacuma saffron in Karabük had the highest amount of volatile compounds
(90.84\%) with bioactive properties, followed in the order by $82.31 \%$ in Yayladağ 1 saffron in Hatay, $79.31 \%$ in Ayaş saffron in Ankara, $77.03 \%$ in Osmaniye Kadirli saffron in Çukurova region and $55.28 \%$ in Korkuteli saffron in Antalya. The fraction of the bioactive volatile components found in the Iranian saffron was $74.41 \%$. It has been reported in the literature that bioactive compounds may differ between dissimilar genotypes or genotypes collected from different geographic regions. ${ }^{27,28}$ Therefore, none of the bioactive components were found at the same amount for all locations. ${ }^{24}$ In a 
study carried out with olfactometric technique, it was reported that 2,3-butanedione was found as a main flavor compound of Spanish saffron. In the same study, many bioactive components including safranal, isophorone, and 4-ketoisophorone were found in the saffron samples. ${ }^{29}$ Isophorones are known to be bioactive and have chemopreventive, antimicrobial and antioxidant activity properties.

Table 5. Bioactive components of saffron samples obtained in Iran and macro and micro locations in Turkey.

\begin{tabular}{|c|c|c|c|c|c|c|c|c|c|c|}
\hline 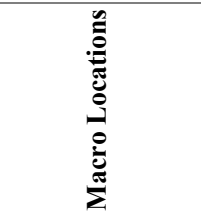 & 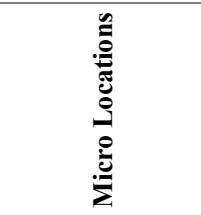 & $\frac{\underbrace{0}_{0}}{\frac{0}{0}}$ & 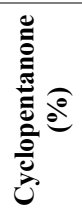 & 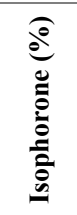 & 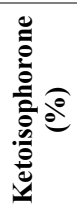 & 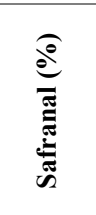 & 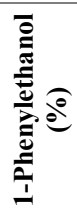 & 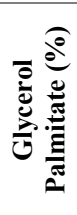 & 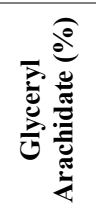 & 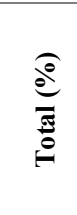 \\
\hline \multirow{4}{*}{ HATAY } & Kirıkhan & 1.24 & 2.48 & 0.00 & 0.63 & 24.47 & 1.81 & 1.38 & 20.71 & 52.72 \\
\hline & İskenderun & 1.74 & 1.20 & 1.44 & 0.64 & 29.51 & 0.46 & 1.37 & 20.16 & 56.52 \\
\hline & Hassa & 1.49 & 1.46 & 1.68 & 0.40 & 28.56 & 0.00 & 1.34 & 15.48 & 50.41 \\
\hline & Yayladağ1 & 0.85 & 0.19 & 0.00 & 0.00 & 75.48 & 0.00 & 0.47 & 5.32 & 82.31 \\
\hline \multirow{2}{*}{ KARABÜK } & $\begin{array}{l}\text { Safranbolu } \\
\text { Yukarıçiflik }\end{array}$ & 1.33 & 0.25 & 0.86 & 0.83 & 64.1 & 0.89 & 0.00 & 7.45 & 75.71 \\
\hline & $\begin{array}{c}\text { Safranbolu } \\
\text { Ovacuma }\end{array}$ & 0.00 & 0.00 & 0.00 & 0.23 & 86.88 & 0.00 & 0.27 & 3.46 & 90.84 \\
\hline \multirow{4}{*}{ ANKARA } & Ayaş & 0.59 & 0.00 & 0.00 & 0.55 & 68.88 & 0.00 & 0.67 & 8.62 & 79.31 \\
\hline & Nallihan & 1.24 & 0.18 & 0.00 & 0.25 & 66.97 & 0.00 & 0.65 & 6.68 & 75.97 \\
\hline & Polatlı & 0.20 & 0.00 & 0.00 & 0.27 & 70.23 & 0.00 & 0.53 & 5.55 & 76.78 \\
\hline & $\begin{array}{c}\text { Adana } \\
\text { Çukurova }\end{array}$ & 2.36 & 0.00 & 0.00 & 0.66 & 65.53 & 0.00 & 0.61 & 6.98 & 76.14 \\
\hline \multirow[t]{2}{*}{ ÇUKUROVA } & Mersin Tarsus & 0.63 & 0.00 & 1.29 & 0.7 & 57.48 & 0.00 & 0.83 & 7.48 & 68.41 \\
\hline & $\begin{array}{c}\text { Osmaniye } \\
\text { Kadirli }\end{array}$ & 0.33 & 0.00 & 0.00 & 0.61 & 68.58 & 0.00 & 0.57 & 6.94 & 77.03 \\
\hline ANTALYA & Korkuteli & 2.30 & 0.00 & 2.61 & 0.83 & 34.67 & 0.00 & 1.24 & 13.63 & 55.28 \\
\hline IRAN & $\begin{array}{c}\text { Rezevi } \\
\text { Horasanı }\end{array}$ & 1.24 & 0.00 & 0.00 & 0.63 & 64.66 & 0.00 & 0.78 & 7.10 & 74.41 \\
\hline
\end{tabular}

\section{CONCLUSION}

In this work, we studied the effects of different geographical locations on the kind and amounts of volatile and fatty acid components of saffron. The results showed a significant effect of the location on the volatile compounds of saffron. On the basis of the obtained results, saffron is an adaptable plant and can be efficiently produced in different geographical and climate conditions. Geographic origin, drying process and different agricultural processes play an important effect on the qualities of saffron and may result in significant differences in the amounts of volatile and bioactive components in saffron samples. According to the obtained outcomes, the highest qualities saffron were determined to be observed in Hatay yayladağ 1 and Karabük safranbolu ovacuma saffron, respectively. Even though Hatay yayladağı and Karabük safranbolu stations located in different geographic regions, their altitudes are very close. Therefore, they probably have similar climate effects on the qualities of saffron.

\section{Conflict of interest}

Authors declare that there is no a conflict of interest with any person, institute, company, etc.

\section{REFERENCES}

1. Hire, R.R.; Srivastava, S.; Davis, M.B.; Konreddy, A.K.; Panda, D. Antiproliferative Activity of Crocin Involves Targeting of Microtubules in Breast Cancer Cells. Sci Rep. 2017, 7(1): 44984.

2. Khorasanchi, Z.; Shafiee, M.; Kermanshahi, F.; Khazaei, M.; Ryzhikov, M.; Parizadeh, M.R.; Kermanshahi, B.; Ferns, G.A.; Avan, A.; Hassanian, S.M. Crocus sativus a natural food coloring and flavoring has potent anti-tumor properties. Phytomedicine. 2018, 43: 21-27.

3. Mir, M.A.; Ganai, S.A.; Mansoor, S.; Jan, S.; Mani, P.; Masoodi, K.Z.; Amin, H.; Rehman, M.U.; Ahmad, P. Isolation, purification and characterization of naturally derived Crocetin beta-d-glucosyl ester from Crocus sativus L. against breast cancer and its binding chemistry with ER-alpha/HDAC2. Suudi J Biol Sci. 2020, 27(3): 975-984.

4. Asil, H. Farklı Depolama Sürelerinin Safranın (Crocus sativus L.) Farmakolojik Ajanlarına (Safranal, Crocin ve Crocetin) Etkisi ve Kalite Özellikleri Bakımından Değerlendirilmesi . Celal Bayar Üniversitesi 
Sağlık Bilimleri Enstitüsü Dergisi. 2021, 8 (2) , 263-269. DOI: $10.34087 /$ cbusbed.804112

5. Lautenschläger, M.; Sendker, J.; Hüwel, S.; Galla, H. J.; Brandt, S.; Düfer, M.; and Hensel, A. Intestinal formation of trans-crocetin from saffron extract (Crocus sativus L.) and in vitro permeation through intestinal and blood brain barrier. Phytomedicine. 2015, 22(1), 36-44.

6. Reddy, C.N.; Bharate, S.B.; Vishwakarma, R.A.; Bharate, S.S. Chemical analysis of saffron by HPLC based crocetin estimation. J Pharm Biyomed Anal. 2020, 181: 113094.

7. Cardone, L.; Castronuovo, D.; Perniola, M.; Cicco, N.; Candido, V. Evaluation of corm origin and climatic conditions on saffron (Crocus sativus L.) yield and quality. J. Sci. Food Agric. 2019, 99(13): 5858-5869.

8. Trimigno, A.; Marincola, F.C.; Dellarosa, N.; Picone, G.; Laghi, L. Definition of food quality by NMR-based foodomics. Curr. Opin. Food Sci. 2015, 4: 99-104.

9. Chichiriccò, G.; Ferrante, C.; Menghini, L.; Recinella, L.; Leone, S.; Chiavaroli, A.; Brunetti, L.; Di Simone, S.; Ronci, M.; Piccone, P.; Lanza, B.; Cesa, S.; Poma, A.; Vecchiotti, G.; Orlando, G. Crocus sativus byproducts as sources of bioactive extracts: Pharmacological and toxicological focus on anthers. Food Chem. Toxicol. 2019, 126: 7-14.

10. Lahmass, I.; Ouahhoud, S.; Elmansuri, M.; Sabouni, A.; Elyoubi, M.; Benabbas, R.; Choukri, M.; Saalaoui, E. Determination of Antioxidant Properties of Six ByProducts of Crocus sativus L. (Saffron) Plant Products. Waste and Biomass Valorization. 2018, 9(8): 1349-1357.

11. Asil, H.; Ayanoglu, F. The Effects of Different Gibberellic Acid Doses and Corm Cutting Methods on Saffron (Crocus sativus L.) Yield Components in Turkey. Fresenius Environ. Bull. 2018, 27(12A): 92229229.

12. Caballero-Ortega, H.; Pereda-Miranda, R.; Abdullaev, F.I. HPLC quantification of major active components from 11 different saffron (Crocus sativus L.) sources. Food Chem. 2007, 100(3): 1126-1131.

13. Fernandez, J.A. Biology, biotechnology and biomedicine of saffron. Recent research developments in plant science. 2004, 2: 127-159.

14. Ben El Caid, M.; Salaka, L.; El Merzougui, S.; Lachguer, K.; Lagram, K.; El Mousadik, A.; Serghini, M.A. Multi-site evaluation of the productivity among saffron (Crocus sativus L.) for clonal selection purposes. J Appl Res Med Aromat Plants. 2020, 17: 100248.
15. Koçer, O, Ayanoğlu, F . Dişi Defne (Laurus nobilis L.) Genotiplerinde Meyve Yağ Asitleri Kompozisyonlarının Belirlenmesi . Uluslararası Doğu Anadolu Fen Mühendislik ve Tasartm Dergisi , 2021. 3 (1) , 72-88 . DOI: 10.47898/ijeased.843773.

16.Koçer, O.; Ayanoğlu, F.; Konuşkan, D.B. Quality Characteristics of Bay laurel (Laurus nobilis L.) Fatty Oils Extracted by Different Methods, 4. International Symposium of Medicinal and Aromatic Plants, 2018

17. Koçer, O.; Ayanoğlu, F.; Konuşkan, D.B. Determination of Suitable Bay Laurel (Laurus nobilis L.) Genotypes for Fruit Growing and Effects of Different Harvest Periods on Fatty Oil Qualit, 4. International Symposium of Medicinal and Aromatic Plants, 2018

18. Carmona, M.; Zalacain, A.; Salinas, M.R.; Alonso, G.L. A new approach to saffron aroma. Crit Rev Food Sci Nutr. 2007, 47(2): 145-159.

19. Gokturk, E.; Asil, H. Hatay/Kırıkhan'da Yetiştirilen Safran (Crocus sativus L.) Stigmasının Ekstraktının GCMS analizi. Türk Tarım ve Doğa Bilimleri Dergisi. 2018, 5(3): 317-321.

20. Koçer, O. Hatay Yöresinde Yetişen Thymbra spicata L. (Zahter/Karabaş Kekiği) Bitkisinin Uçucu Yağ Oran ve Bileşenlerinin Belirlenmesi. Avrupa Bilim ve Teknoloji Dergisi , 2021. (27) , 446-449 . DOI: 10.31590/ejosat.963053

21. Rezaee, R.; Hosseinzadeh, H. Safranal: from an aromatic natural product to a rewarding pharmacological agent. Iran. J. Basic Med. Sci. 2013, 16(1): 12-26.

22. Culleré, L.; San-Juan, F.; Cacho, J. Characterisation of aroma active compounds of Spanish saffron by gas chromatography-olfactometry: Quantitative evaluation of the most relevant aromatic compounds. Food Chem. 2011, 127(4): 1866-1871.

23. Farag, M.A.; Hegazi, N.; Dokhalahy, E.; Khattab, A.R. Chemometrics based GC-MS aroma profiling for revealing freshness, origin and roasting indices in saffron spice and its adulteration. Food Chem. 2020, 331: 127358 .

24. Anastasaki, E.; Kanakis, C.; Pappas, C.; Maggi, L.; Del Campo, C.P.; Carmona, M.; Alonso, G.L.; Polissiou, M.G. Geographical differentiation of saffron by GCMS/FID and chemometrics. Eur. Food Res. Technol. 2009, 229(6): 899-905.

25. Bononi, M.; Milella, P.; Tateo, F. Gas chromatography of safranal as preferable method for the commercial grading of saffron (Crocus sativus L.). 2015, Food Chemistry. 176: 17-21. 
26. Rahimi, A.; Rezaee, M.B.; Jaimand, K.; Ashtiany, A.N. Effects of Storage and Cultivation on Crocin Content of Dried Stigma of Saffron Crocus sativus L. Akademik Gida. 2014, 12(1): 16-19.

27. Sampaio, B.L.; Edrada-Ebel, R.; Da Costa, F.B. Effect of the environment on the secondary metabolic profile of Tithonia diversifolia: a model for environmental metabolomics of plants. Sci. Rep. 2016 , 6(1): 29265
28. Vahedi, M.; Kabiri, M.; Salami, S.A.; Rezadoost, H.; Mirzaie, M.; Kanani, M.R. Quantitative HPLC-based metabolomics of some Iranian saffron (Crocus sativus L.) accessions. Ind Crops Prod. 2018, 118: 26-29.

29. Amanpour, A.; Sonmezdag, A.S.; Kelebek, H.; Selli, S. GC-MS-olfactometric characterization of the most aroma-active components in a representative aromatic extract from Iranian saffron (Crocus sativus L.). Food Chem. 2015, 182: 251-256. 